развивающие: развитие интеллектуальных, лингвистических качеств, творческих способностей;

воспитательные: формирование культуры спора, терпимости, признание множественности подходов к решению проблемы;

коммуникативные: учебная деятельность осуществлялась в межличностном общении, обучение происходило в процессе совместной деятельности [2].

$$
* * *
$$

1. Деркач А.А., Щербак С.Ф. Педагогическая эвристика: искусство овладения иностранным языком/ А.А. Деркач, С.Ф. Щербак. - М.: Педагогика, 1991. - 224c.

2. Львова О.В. Использование технологии «дебаты» при обучении иностранному языку.[Электронный ресурс]. - Режим доступа: http://www.intelros.ru/readroom/guminitarnye-nauki/gum12014/24170ispolzovanie-tehnologii-debaty-pri-obuchenii-inostrannomu-yazyku.html

3. Мотайло Л. А. Образовательная технология «Дебаты» как фактор повышения качества обучения иностранному языку и средство формирования общекультурных и профессиональных компетенций [Текст] / Л. А. Мотайло // Modern education development theory techniques and practice : материалы VII Междунар. науч.-практ. конф. (Cheboksary, 29 мая 2016 г.) / редкол.: О. N. Shirokov [и др.]. Cheboksary: ЦНС «Интерактив плюс», 2016. - № 1 (7). - С. 317-319. - [Электронный ресурс]. Режим доступа: https://interactive-plus.ru/e-articles/219/Action219-80482.pdf

\begin{tabular}{l} 
4. Светенко, Т.В. Путеводитель по дебатам для школьников и студентов: [Учебное \\
\hline
\end{tabular} пособие]/Т.В.Светенко, И.В.Галковская. - 2 -е изд., испр. и доп.- Псков: ПГПИ, 2001.- 151с.

5. Should Animals Be Used for Scientific or Commercial Testing? - [Электронный ресурс]. - Режим доступа: https://animal-testing.procon.org/

\title{
Вознюк Н.А. \\ Приемы мнемотехники при изучении лексических единиц иностранного языка. (Teaching foreign languages words using mnemotechniques (mnemonics)
}

ФГКОУ «Кызылское президентское кадетское училище» (Россия, Kblзыlд)

doi 10.18411/spc-04-10-2017-02

idsp 000001:spc-04-10-2017-02

\section{Аннотация}

Практика преподавания иностранных языков показывает, что в методике преподавания иностранных языков, на наш взгляд, недостаточно разработаны вопросы, ориентированные на запоминание лексических единиц посредством увеличения объема памяти обучающихся. Возможно, данная статья поможет преподавателям пополнить их методический багаж при разработке уроков иностранного языка, опираясь на знания о приемах мнемотехники.

\section{Abstract}

Everyday practice of foreign language teaching demonstrates lack of attention to ways of teaching by the improving memory ability of the students in language learning. This article aims at helping teachers of foreign languages to employ mnemotechniques (mnemonics) at their foreign language classes.

В современном мире появилась потребность в том, чтобы высококвалифицированный специалист знал несколько иностранных языков, вследствие этого, иностранные языки преподают во всех учебных заведениях: в школах, в училищах, в институтах и т.д.

Не секрет, что знание именно английского языка стало требованием в ряде направлений, специальностей и профессий, таких как медицина, вычислительная техника, инженерия и т.д.

Сложность изучения иностранного языка заключается в том, что в ходе обучения необходимо запомнить несколько сотен, а то и тысяч новых слов. Очевидно, 
что для изучения английского языка, необходимо обладать хорошей памятью. Благодаря памяти обучающийся способен запоминать огромное количество новых иностранных слов, правил, а в последующем применять их на практике. Память считается основным условием успешного обучения и очень важно развивать ее для дальнейшего самосовершенствования [7].

Авторы учебников иностранных языков на практике вообще не рассматривают тему запоминания новой лексики и фраз. Предполагается, что обучающиеся естественным образом, в процессе выполнения большого количества упражнений освоят новый лексический материал.

На первый взгляд задача кажется невыполнимой без специального обучения технике запоминания.

В действительности иностранные слова запоминаются гораздо легче, если владеть специальной методикой запоминания. Таким образом, применение специальной техники запоминания - «мнемотехники» делает процесс изучения языка более осмысленным, быстрым, качественным и полностью контролируемым.

Слова «мнемотехника» и «мнемоника» обозначают одно и тоже - техника запоминания. Они происходят от греческого «mnemonikon»- искусство запоминания. Считается, что это слово придумал Пифагор Самосский (6 век до н.э.).

Современный энциклопедический словарь дает следующие определения мнемотехники.

Мнемоника - искусство запоминания, совокупность приемов и способов, облегчающих запоминание и увеличивающих объем памяти путем образования искусственных ассоциаций.

При изучении иностранного языка укрепляется память; происходит улучшение работы головного мозга; увеличивается объем долговременной памяти, за счет пополнения словарного запаса на иностранном языке. В процессе изучения языка, обучающиеся пытаются механически запомнить большое количество информации, что очень неэффективно, естественно таким образом можно запомнить информацию, но ненадолго.

Процесс запоминания иностранных слов, отдельных словосочетаний, предложений в мнемотехнике носит по сути естественный характер, его можно сравнить с тем, как учит родной язык ребенок. Смысл запоминания новых иностранных слов можно выразить в следующем вопросе: "А как носитель языка, например, англичанин называет этот зрительный образ?" После запоминания новых слов путем установления связи между образом и его новым словесным обозначением, понятие "перевод" не является главенствующей составляющей при изучении иностранного языка. Таким образом, иностранная речь понимается наподобие речи на родном языке (образы возникают в воображении рефлекторно под стимулирующим действием слов).

Смысл запоминания иностранного слова заключается в установлении устойчивой рефлекторной связи между уже имеющимся в сознании зрительным образом (образ кошки, например) и его новым словесным обозначением (английское слово "cat"). Когда такая связь будет установлена, то при восприятии слова "cat" в воображении изучающего иностранный язык автоматически будет возникать образ кошки, благодаря которому он будет понимать это слово.

Слово - это стимул, поступающий в мозг. А зрительный образ - это реакция мозга, обеспечивающая понимание этого слова. Рефлекс должен работать автоматически и мгновенно. Если этой взаимосвязи нет, значит, рефлекс не образован. А если он не сформирован, то, несмотря на положительные оценки за тестовые работы по лексике, обучающийся забудет новую лексику в самое ближайшее время. Причем следует отметить, что забудет их полностью. Вплоть до того, что будто никогда их раньше не учил. 
Если же обучающийся запоминает фразы с помощью мнемонических методов, то эти фразы сами крутятся в голове, как навязчивые ритмы знакомых песен. Начинают сниться сны на изучаемом языке - это и будет являться верным признаком качественного запоминания слов и фраз.

Один из эффективных факторов от применения мнемотехники при обучении английскому языку является то, что появляется интерес к изучению иностранного языка. А при его изучении такой мотивирующий фактор как заинтересованность крайне необходим и, следовательно, процесс обучения носит продуктивный и продолжительный характер.

$$
* * *
$$

1. Артемов В.А. Психология обучения иностранным языкам. - М.: Просвещение, 1969. - 279 с.

2. Беляев Б.В. Очерки по психологии обучения иностранным языкам. 2-е изд. - М.: Просвещение, 1965. - $229 \mathrm{c}$.

3. Блонский П.П. Память и мышление. - Соч.-М.,1979, т. 2, с. 118-340.

4. Зимняя И.А. Психология обучения иностранным языкам в школе. М.: Просвещение, 1991. - 222 с. - (Библиотека учителя иностранного языка).

5. Рогов Е.И. Общая психология: Курс лекций для первой ступени образования. / Сост. Е.И. Рогов. М.: Гуманит. Изд. Центр ВЛАДОС, 2002. - 448 с.

6. Словарь практического психолога / Сост. С.Ю. Головин: Харвест; Минск; 1998

7. Черемошкина, Л.В. Психология памяти. - М.: Академия, 2002. -368c

\section{Григорян А.Г. \\ Использование интерактивных методов при обучении страноведению в рамках дисциплины «Иностранный язык» в средней школе}

МКОУ СОШ№ 1

(Россия, Сосенский)

doi 10.18411/spc-04-10-2017-03

idsp 000001:spc-04-10-2017-03

Развитие социально-экономических отношений в современном мире выдвигает новые требованияи ставит новые задачи в обучении иностранному языку в средней школе. В настоящее время изучение иностранного языка невозможно представить без изучения культуры, традиций страны изучаемого языка, так как иностранный язык очень тесно переплетен с культурными особенностями англоговорящих стран. Исследования многих российских ученых (Верещагина Е.М.,Костомарова В.Г. «Лингвострановедение в преподавании русского языка как иностранного», ТерМинасовой С.Г. «Язык и межкультурная коммуникация», Н.Д.Арутюновой «Язык и мир человека», В.А.Масловой «Язык и мир человека») показывают, что если обучение иностранному языку ограничивать обучением языковой системе или овладению только коммуникативной речевой компетенцией, знания языка у обучающихся будут неполноценными, поэтому в настоящее время, при преподавании иностранного языка все больше и больше внимания уделяют изучению культурным традициям, истории, менталитетам народов изучаемого языка, особенностям национального характера, что подразумевает не простое получение информации об изучаемых странах, а формирование способностей и умений в общении и обращении с другими культурами.

Как говорит С.Г. Тер- Минасова:«Каждый урок иностранного языка — это перекресток культур, это практика межкультурной коммуникации, потому что каждое иностранное слово отражает иностранный мир и иностранную культуру: за каждым словом стоит обусловленное национальным сознанием представление о мире».

В настоящем времени изучение культур и традиций англоязычных стран приобретает иной характер, так как современный мир характеризуется сплетением культур разных стран или так называемым процессом глобализации. Глобализация 